\section{Vaccines for neglected and emerging diseases in Brazil by 2030: the "valley of death" and opportunities for RD\&I in Vaccinology 4.0}

\author{
Vacinas para doenças negligenciadas e emergentes \\ no Brasil até 2030: o "vale da morte" e oportunidades \\ para PD\&I na Vacinologia 4.0
Vacunas en Brasil para enfermedades emergentes y olvidadas en 2030: el "valle de la muerte" y oportunidades para RD\&I en Vacunología 4.0

Akira Homma 1

Marcos da Silva Freire 1

Cristina Possas 1

\begin{abstract}
We examine the implications of the very low competitiveness of the Brazilian vaccine RD.SI system, which precludes the development of all the important vaccines required by the National Immunization Program (NIP), severely impacting the healthcare of the population. In a country dramatically affected by COVID-19 pandemic and by an exponential increase in emerging and neglected diseases, particularly the poor, these RD.EI constraints for vaccines become crucial governance issues. Such constraints are aggravated by a global scenario of limited commercial interest from multinational companies in vaccines for neglected and emerging diseases, which are falling into a "valley of death," with only two vaccines produced in a pipeline of 240 vaccines. We stress that these constraints in the global pipeline are a window of opportunity for vaccine manufacturers in Brazil and other developing countries in the current paradigm transition towards Vaccinology 4.0. We conclude with recommendations for a new governance strategy supporting Brazilian public vaccine manufacturers in international collaborations for a sustainable national vaccine development and production plan by 2030.
\end{abstract}

Vaccines; Scientific Research and Technological Development; Governance

\section{Correspondence}

C. Possas

Instituto de Tecnologia em Imunobiológicos, Fundação Oswaldo Cruz.

Av. Brasil 4365, Rio de Janeiro, RJ 21045-900, Brasil. cristina.possas@bio.fiocruz.br

1 Instituto de Tecnologia em Imunobiológicos, Fundação Oswaldo Cruz, Rio de Janeiro, Brasil. 


\section{Introduction}

Successful national policies for vaccine innovation, technological development and production require adequately understanding the global scientific, technological and market scenarios in which they are embedded. From this perspective, we examine here the conditions underlying the very low competitiveness of the national vaccine research, development and innovation (RD\&I) system in Brazil, due to lack of an integrated government policy and a low and dispersed financial support for this area, which preclude the development of important vaccines required for the National Immunization Program (NIP).

These major constraints to vaccine RD\&I and production for emerging and neglected diseases contrast with an exponential increase in the global market for vaccines against other diseases. This is a scenario of great concern for Brazil, one of the countries in the world mostly affected by neglected and emerging diseases, such as dengue, Zika, chikungunya, malaria, and others, rapidly disseminating in the country's complex eco-social conditions.

The global constraints by multinational pharmaceutical companies for these vaccines is a window of opportunity for vaccine manufacturers in Brazil and other developing countries in the current paradigm transition from Vaccinology 3.0 to Vaccinology 4.0.

We conclude with governance proposals to support these public manufacturers in national and international collaborations and to strengthen their local scientific and technological capacity towards a successful and sustainable national vaccine development and production plan by 2030 .

\section{New generations of vaccines: transition to Vaccinology 4.0}

Global and national strategies in vaccine development for neglected and emerging diseases require understanding scientific and technological paradigms in which they are formulated. The evolution in generations of vaccines and technologies is forwarded in sequence 1,2,3.

Disease prevention with inoculation ("variolation") has a long history. Inoculation against smallpox in China can be found as early as the late 10th century, and the procedure was widely practiced by the 16th century, during the Ming dynasty.

Conventional vaccinology was officially born in 1796, thanks to Edward Jenner (1749-1823), who developed the smallpox vaccine. Vaccinology 1.0 further proceeded with the invention of the rabies vaccine, which was the first human vaccine developed in the laboratory by Louis Pasteur in 1885. Other "first generation" vaccines are the Calmette-Guérin (BCG), plague, inactivated pertussis, tetanus and diphtheria toxoids, and anthrax vaccines.

"Second generation" vaccines (2.0) has emerged from several technological advances, with new technologies for bacterial and virus purification and tissue culture, which resulted in viral vaccines against yellow fever, inactivated and live attenuated poliomyelitis, measles, mumps, rubella, inactivated hepatitis B, polysaccharides meningococcal meningitis, Japanese encephalitis, Lyme disease and rabies in tissue culture 2,3.

The current third generation of Vaccinology (3.0) has emerged from innovations and technological developments in the fields of DNA recombinant, reverse technology, chemical conjugation, genomics and proteomics, such as meningitis, meningococcal serogroup B, Haemophilus influenzae type b (Hib), pneumococcal and meningitis meningococcal conjugated, hepatitis B, rotavirus and HPV 2,3.

These breakthroughs had an extraordinary impact on the development of new vaccines and resulted in most of the recent developments in complex combined multipatented vaccines 4 . These advances resulted from the sequencing of microbial genomes and made all potential antigens of each pathogen available for the development of vaccines, thereby increasing potential targets vaccines in bacteria, parasites and viruses, revealing their CD4+ and CD8+ T cell epitopes 5 .

Recently, significant advances in the field of immunology and immunoinformatics (such as the manipulation of a large immune system database, the Immunome Project) allow us to visualize the emergence of a new generation of immunobiologicals (4.0) with vaccines and individualized immunotherapies designed according to individual genetic profiles, thereby significantly reducing their adverse events. 
In Brazil, Vaccinology 1.0 began in 1894, with baron Pedro Afonso producing the cowpox virus on calf flanks at the Municipal Vaccine Institute, making it possible to expand the production of the vaccine in the country 6 . In 1919, this activity was transferred to the Oswaldo Cruz Institute (IOC), which started to produce this vaccine in response to all national demand.

At the beginning of the last century, the IOC under the command of Oswaldo Cruz developed and produced several important immunobiologicals for public health, such as the vaccine against symptomatic carbuncle in cattle. It was patented, developed and produced by Alcides Godoy in 1908, based on the attenuation of Clostridium chauvoei, improving the previous discovery of this vaccine by Pasteur. Since 1937, the Institute has been producing the yellow fever vaccine.

In 1965, President Castelo Branco created the Smallpox Eradication Campaign (SEC). In this context, there were substantial improvements in production, thermostability, quality control and scale of production. Between 1966 and 1971, Brazil produced more than 260 million doses of smallpox vaccine, and more than 81 million people were immunized. The incremental innovations introduced in vaccine production were supported by the Pan American Health Organization (PAHO) and Canada's Connaught Laboratory.

The last 19 cases of smallpox were registered in the city of Rio de Janeiro. In 1973, the Brazilian government received a certificate of smallpox eradication. Global eradication of smallpox occurred on May 8, 1980, and it was an extraordinary achievement of International Public Health 6,7.

At the beginning of the 20th century, the Butantan Institute was created, linked to the Secretary of Health of São Paulo, by Vital Brazil, who was an extraordinary researcher and entrepreneur. He discovered the specificity of snake venoms, showing that serums made from venoms from other regions of the world did not protect against snakebites from Brazil. Under his direction, the Butantan Institute became the largest center for development and production of antiophidic, anti-venom, and antitoxic sera. The Institute has expanded later its array of products, including the DTP, Dt, the antirabies vaccine and the recombinant technology hepatitis vaccine.

In the 1970s, with the reorganization of the Oswaldo Cruz Foundation and the creation of the Institute of Technology in Immunobiologicals (Bio-Manguinhos), the institute has become a reference for the Ministry of Health/NIP and expanded its portfolio with the production of modern vaccines, kits for IVD (in vitro diagnosis) tests and biopharmaceuticals.

In Brazil, the centennial national development and production of vaccines and other biological products by leading public manufacturers such as Bio-Manguinhos/Fiocruz and the Butantan Institute in support to the Ministry of Health, has created a tradition of presence, leadership, trust and singular action in the development and production of strategic inputs for public health. This tradition, supported by social recognition, has shown for more than 100 years the crucial role and importance of public production in the country's public healthcare.

Nevertheless, despite advances by public vaccine manufacturers in vaccine RD\&I and production, the development of new and innovative vaccines for emerging and neglected diseases remains a major challenge for the country. The increasing complexity in the development of these vaccines and the local and global constraints for vaccine RD\&I will require a radical change from policy makers in governance paradigms and strategies for vaccine development and production.

\section{Increasing demand for vaccines: emerging neglected diseases}

Emerging and neglected diseases are a major public health problem for developing countries, particularly in Latin America and Africa, for the severity of their symptoms and lethality. In Latin America, Brazil has been severely affected by them, particularly by arboviral diseases such as Zika, dengue, yellow fever and chikungunya. In the last two decades, the rapid global dissemination of these diseases in Brazil and the risk of reurbanization of yellow fever in the country, particularly in large metropolitan areas such as in Rio de Janeiro, São Paulo, and other cities, have become a major concern for policy makers: COVID-19 pandemic has dramatically aggravated this scenario 8 .

Changes in eco-social conditions, such as climate change, poverty, forest devastation, intensification of travel and increasing population mobility, with poor sanitation and garbage collection, and other factors, have contributed to the rapid proliferation of mosquito-vectors carrying several emerg- 
ing and neglected diseases, thus aggravating the complex epidemiological scenario in the country. This scenario has dramatically increased the need for new vaccines and therapeutic strategies, namely several arboviruses, such as Mayaro, Oropouche, West Nile, and others, which creates challenges for priority-setting in research 9,10 .

In Brazil, this scenario for emerging and resurgent arboviruses highlights a great challenge for vaccine RD\&I, since several pathogenic agents are concentrated in a same site/region and co-infection occurs, such as dengue, Zika, chikungunya, yellow fever and other arboviruses. Combined vaccines are required in these situations. It is urgent therefore to organize a national plan to develop combined vaccines for these viruses in order to assure an efficacious vaccination program. It is not sufficient to have a dengue vaccine, if Zika and chikungunya are causing severe epidemics.

The increasing demand for vaccines is contrasted with the low profitability and low commercial interest of companies on development and production on vaccines for emerging and neglected diseases, in spite of the exponential increase in the global vaccine market for other profitable vaccines, as indicated in Figure 1.

This low interest in vaccines for emerging neglected diseases appears in a global context of decreasing coverage of vaccination. This decrease, related to loss of memory of epidemics by the new generations and exacerbation of adverse effects in social networks by anti-vaccine and religious groups, has led to a significant increase in vaccine refusal and vaccine hesitancy indicators in many countries. It is interesting to note that all these concerns on the adverse events from vaccines are merely perceptions and lack scientific support. A recent article in the New York Times 11, based on indicators from a federal program designed to compensate people harmed by vaccines, showed that vaccine injury claims are few and that it is rare for someone to claim they were affected by adverse events after getting vaccinated.

In Brazil, there has been a significant decline in vaccination coverage in the last decade, according to the Ministry of Health 9,12. This has been a major concern for authorities and society, with

\section{Figure 1}

Global scenario challenging vaccine research, development and innovation (RD\&l).

\section{Global scenario: drastic changes challenging vaccine RD\&|}

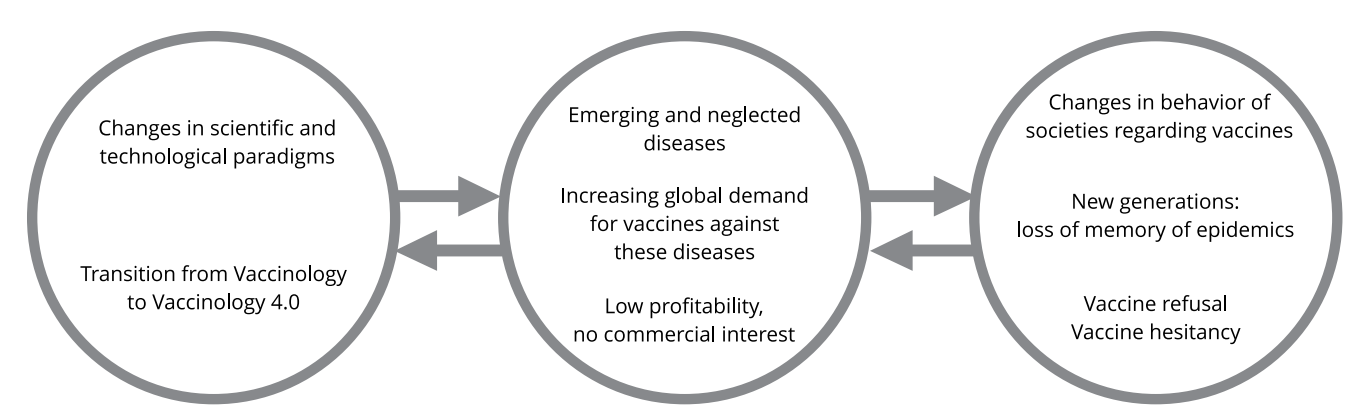

EXPONENTIAL INCREASE IN THE GLOBAL VACCINE MARKET

Source: elaborated by the authors. 
resurgence of several diseases previously under control or eliminated, such as yellow fever (with risk of reurbanization), measles (migration of cases from Venezuela), mumps, pertussis and diphtheria.

The reasons for this decline are complex and multifactorial and it would be premature, due to lack of scientific evidence, to attribute them to governance issues, to vaccine refusal or to vaccine hesitancy, in spite of some indications that vaccine hesitancy might be increasing in the country 9 .

\section{Barriers to access: "valley of death" for vaccine RD\&I}

The extraordinary scientific and technological breakthroughs in recent decades in the fields of molecular biology, recombinant DNA, genomics, proteomics, expression technologies and antigen production have impacted on the global vaccine pipeline and production. These achievements resulted from the enormous investments in basic and translational research as well as technological innovation, from proof-of-concept to discovery.

Large multinational pharmaceutical companies are exponentially increasing their investments in the development of new innovative vaccines, with reduced adverse effects and without the need for revaccination.

Nevertheless, the poorest populations of Brazil and other developing countries would have difficulty in accessing these new vaccines, due to their very high initial costs and small scales of production, offered to the populations of the richest countries. Technological, regulatory, patent, financing and governance issues must be overcome so national public laboratories have the opportunity to incorporate these new technologies and make them available for the population.

The global epidemiological scenarios for emerging and neglected diseases, aggravated by complex eco-social conditions and population mobility and aging, are a major concern for international authorities and governments. Some of the issues include: the risk of an influenza pandemic and the resurgence of Ebola; the increase in HIV infections, which currently exceed 36.9 million worldwide; the global growth of new HPV-related cancers, currently with 670,000 cases annually; the emergency and the increase in Zika with more than 86 countries reporting 230,000 confirmed cumulative cases of infection between 2015-2018; herpes simplex (HSV); tuberculosis; 10 million infected globally and 1.5 million deaths every year despite progress made to eliminate the disease 9,13,14.

Currently, there are 240 vaccine candidates under development for emerging diseases that mainly affect the poorest countries such as malaria, dengue, HIV, tuberculosis and pneumonia, and only two of them have been able to achieve their goals and are widely used in these countries: a conjugate vaccine for serogroup A meningitis and a vaccine against Japanese encephalitis virus 15.

Unfortunately, much of these promising products could fall into the so-called "valley of death," failing to move from proof-of-concept to second-stage testing due to lack of market interest in vaccines against these emerging and neglected diseases that affect only the populations of developing and poor countries 15 . These are vaccines without a private market and, therefore, without economic return. Consequently, it may take many decades for these vaccines to complete phase 3 of clinical studies, be registered and incorporated into the national immunization programs in poorer countries.

\section{Flow of vaccine development: complexity}

There are several steps in the RD\&I flow of vaccine development with specific goals and infrastructure needs, such as laboratory facilities, equipment, supplies, and especially trained human resources. The professional profile is also specific to each stage, depending on different scientific and technological approaches and requirements.

Early activities, the stages of discovery, pre-development and the initial technological development, up to proof-of-concept, are financed by the federal and state governments in universities and research institutions. These activities require enormous investment in facilities, equipment, human resources and therefore, represent a high cost, with high financial risk, due to the low guarantee of economic return. This provides no incentive for the private sector. 
With positive results in proof-of-concept, incentives to private companies increase, providing significant investments for the development of the next stages, or even for purchasing new technology.

It is also worth noting that the RD\&I process to develop a vaccine is, by definition, long-term (1020 years), with multiple stages, each with specific objectives and requirements, high-cost and with uncertain return.

In the preclinical study, we show two important aspects for the project to follow, which is safety and immunogenicity, before being applied to humans. In addition, other issues, such as toxicity and tumorigenicity are examined. Preclinical studies require sanitary and genetically controlled certified animals, as well as large investments in specialized human resources and facilities, supported by good animal experimentation practices (GAEP), among many other requirements. Pre-clinical studies are one of the main bottlenecks for the process of innovation and technological development of immunobiological products in our country. Therefore, it is an area where private initiative has difficulty participating in, and, even in developed countries, it has strong support from governments.

The "gaps" mentioned here are the result of several constraints, related to the development of vaccine production, quality control, among others.

The accelerated global development of basic science and technology in this area obliges production laboratories to adopt technologies, such as 4-D computing, robotization, replacement of animals in toxicity exams, immunogenicity or even better targeting for vaccines. The new technology for sterility testing, which includes the use of nuclear acidification (NAT) technology and micro-arrays for detection of microorganisms, also must be adopted.

The vaccines currently used in NIP require both incremental and disruptive innovation. There is no vaccine that grants lifetime protection - it is necessary to apply multiple doses to obtain adequate protection. The production technology of the DTP vaccine is the delayed century - over 70 years -, which requires three doses for complete immunization, with whooping cough as a determinant for adverse reactions. It is important to note that antigenic fractions of Bordetella pertussis have less efficacy when compared to whole cells.

On the other hand, it is also necessary to define the role of B. parapertussis and other bacteria in bronchial diseases. Disruptive innovation at a very low price regarding these vaccines is necessary due to their global use; but this would certainly not arouse the interest of any laboratory in investing in their research. Some important developments required are:

- Alternatives to injectable administration, a hindering factor in the acceptance of the vaccine. Children receive injectable vaccines under parental agreement, but injections cause fear in adults, especially in men. It is necessary to find alternatives such as patches, inhaled and oral vaccines, sublingual administration, capsules, pills, or intradermal injection.

- New combined vaccines, containing a greater number of vaccine antigens, in order to decrease the number of visits to vaccination centers. Some examples of combined vaccines that could be developed: ABCWY, conjugated/protein meningitis; pneumococcus conjugated 10 valent + meningitis ABCWY Rotavirus + Norovirus + OPV.

- Improve Influenza vaccine. Flu/influenza is a disease that has determined global pandemics. The current influenza vaccine has the lowest efficacy among all vaccines. In order to obtain adequate protection, annual revaccination is necessary.

- Influenza viruses are characterized by changing their antigenic properties very quickly. These viral antigenic shifts of influenza, with combinations and/or mutations varying in magnitude, occur in the interaction of viruses with humans and animals, such as swine, poultry or others. These new viruses infect the population without antibodies, and even those vaccinated with different strains become ill from exposure to the new influenza virus strain. Major epidemics occur when these viral shifts happen, such as the one in 1957, the 1968 Asian flu and the 1968 Hong Kong flu, which caused 2 million deaths. In 2009, the swine flu epidemic resulted in 600,000 deaths. The 1918 Spanish flu pandemic, determined by the H1N1 virus, has decimated between 50 and 100 million people worldwide, and many doctors call it "the greatest medical holocaust of history".

Scientists have used supercomputers to analyze the genetic sequences of circulating H1N1 flu viruses among humans since 1918. The computers found evolutionary variations throughout the virus, but in the most exposed the variation was always much greater. A universal flu vaccine would certainly be far more protective than the ones we use now. 
All these development or improvement projects for neglected diseases are considered close to or within the so-called "valley of death", given the difficulty of making them possible.

A recent study in Brazil, in collaboration with the Rockefeller University (New York, USA) 16, reported the first genetic cause of viscerotropic disease associated with adverse events due to yellow fever vaccine (YFV-AVD). IFNAR1 (interferon alpha receptor 1) is the first genetic etiology identified in adverse events related to this vaccine. Type 1 IFNs are important for the control of adverse reactions to MMR (measles, mumps and rubella) and yellow fever vaccines 17 . More in-depth genetic studies will be crucial for advancement in the field of individual genetic profiling to adverse events, which, in the future, could be anticipated and prevented from biomarkers.

In summary, the complexity of new biopharmaceutical processes that consider individual genetic profiles in the search for reduction in vaccine adverse events, imposes the need for paradigmatic changes in the formulation of innovation, technological development and production policies. A good example of these paradigm shifts in the field of vaccines is the first sequencing of the human immune system.

The Human Vaccines Project published earlier this year in the journal Nature the first results of the effort to sequence the human immunome - the "Immunome Project" 18. The study, led by James Crowe from Vanderbilt University Medical Center in the United States, begins to define for the first time the genetic basis of our ability to respond and adapt to many disease threats. So far, this was considered a very large and complex project to undertake, since the human immune system is billions of times larger than the human genome.

This study complements another study by a Scripps Research group, a scientific partner of the Human Vaccines Project, who used different methods to describe the sequencing of the human immune system 19 . This new scientific and technological scenario introduced by the Immunome project, called Immunology 2.0, combining System Biology with Artificial Intelligence, will profoundly change the field of vaccines, immunotherapies, and immunobiological products 18,19,20.

In the Fourth Industrial Revolution, the biopharmaceutical industry has rapidly incorporated, as the Immunome Project illustrates, the Big Data Analytics, associated with the Internet of Things (IOT) and Artificial Intelligence, which will certainly allow a qualitative leap in the field of vaccines and other immunobiological products. Disruptive innovation will challenge the current regulatory requirements and improve quality control and safety in the production process.

From this perspective, clinical trials will be improved to fit this new environment of innovation and regulation, and regulators shall adapt 21,22. New strategies such as Randomized Clinical Trials (RCTs) will be strengthened by Real World Data (RWD), with evidence and pragmatic clinical trials becoming increasingly common 21 . Volunteers in the clinical trial will be reduced dramatically by intense use of new technologies that will provide new and complete information related to the individual immune response and behavior to the agent study.

\section{Vaccine RD\&I: window of opportunity for Brazil}

Although Brazil has made investments in vaccine RD\&I and production, the national public manufacturers have historically invested very little, compared to the large investments of the multinational enterprises. There are no local private investments in this area, and important gaps persist in vaccine development and production in the country, particularly related to the pre-clinical phase and technological platforms.

Strong governance is thus required to overcome these challenges, based on national long-term strategies, technological forecast, reversal of importation rules for new licenses or transfer of technology, and rapid incorporation of new technologies into the production of new vaccines. A new governance model should be thus conceived, based on "mission-oriented" approaches to accelerate vaccine innovation 23,24 .

The complexity of the epidemiological scenario, with major outbreaks of emerging and re-emerging diseases such as Zika, dengue, chikungunya, influenza and HIV/AIDS will require a National Strategic Plan for the development of new vaccines and fast-track health regulation, in order to accelerate the introduction of these vaccines in the Brazilian Unified National Health System (SUS). 
Preventive vaccines continue to be the most effective alternatives to deal with the emergence and resurgence of infectious and parasitic diseases. The accelerated global development of the Ebola vaccine has contributed to a comprehensive strategy to develop effective tests, vaccines and drugs at a much faster pace during epidemics.

Bio-Manguinhos/Fiocruz, despite the persistence of obstacles resulting from its current administrative/legal structure and financing mechanisms, has contributed to the creation a reasonable installed capacity for the production of vaccines. Bio-Manguinhos and the Butantan Institute already account for $70 \%$ of the demand of the Brazilian public sector. These advances resulted from the important governmental support to the National Immunobiological Self-Sufficiency Program (PASNI), created in the mid-1980s, which has ensured, for more than ten years, the modernization of public vaccine manufacturers and the production of quality vaccine products $25,26,27$.

However, this is an area of enormous and rapid evolution that requires new strategies to face the future scenarios of increasing demand for technological competitiveness and self- sustainability. To overcome this critical situation of constraints in the country's technological and industrial capacity in this area, the Brazilian government has implemented Partnerships for Productive Development (PPDs) as a central component of its industrial policy 9 .

The consolidation of Bio-Manguinhos as a reference in immunobiological products can only occur with institutional restructuring in order to meet the increasing complexities in issues related to the accelerated advance of new technologies and demand for new quality products. The sustainability and competitiveness of this public manufacturer must be aligned with the reconfiguration of the global market.

A significant increase in exportation for developing countries and for emerging countries must be part of this new vision. Indeed, these institutional needs and trends should be examined from a broader perspective considering the growing global demands for innovation and technological development in the context of the international initiative of the Decade of Vaccines Collaboration 28 , by intensifying and accelerating public-private partnerships for the development and production of innovative vaccines.

In previous publications 28 , we stressed that if there is no rapid reversal in this trend, it will result in a detrimental international division of the immunobiological market: while producers in developed countries and even in some emerging countries, such as India, South Korea and China have been expanding their participation in the market for innovative and more profitable products, producers in developing countries tend to limit their activities to the market for traditional immunobiological products, despite their efforts to reverse this scenario 29,30 .

These initiatives require in the long-term a National Strategic Plan that results from critical considerations on the historical, cultural and psychosocial constraints involved in the vaccine innovation process in Brazil, which necessarily will demand creating an institutional and cultural environment that favors the synergy and collaboration from the diverse actors in vaccine development 9.

National vaccine production goals have been largely achieved by Bio-Manguinhos and the Butantan Institute, both Institutes have made significant progress over the years, incorporating and developing the technologies of production of important vaccines for the NIP, contributing to the national capacity for production of vaccines. Their participation in the public market of vaccines in the country is indicated in Figure 2.

It is important to note that several other new vaccines are now in development and should be included in NIP: the new tuberculosis vaccine, as well as the ones for HIV, and leishmaniosis. Molecular biology currently allows for the development of innovative vaccines of fast production, which was not previously possible 31,32 . It is necessary therefore to understand the enormous challenges of vaccine-related policies, which will require, particularly from developing countries, the incorporation of new paradigms for sustainable and long-term governance 33 . To achieve this goal, it will be necessary to try a new scientific approach in an innovative way, as in the Pasteur model: research to solve public health problems and not to reproduce existing knowledge and practices 34 .

A major constraint is the lack of long-term and sustainable governmental funding and incentives in spite of the success of some important vaccine RD\&I initiatives, such as PPDs by the Ministry of Health and the funding mechanisms by governmental agencies such as Brazilian National 


\section{Figure 2}

Participation of national and international manufacturers in the Brazilian public market of vaccines, 2018.

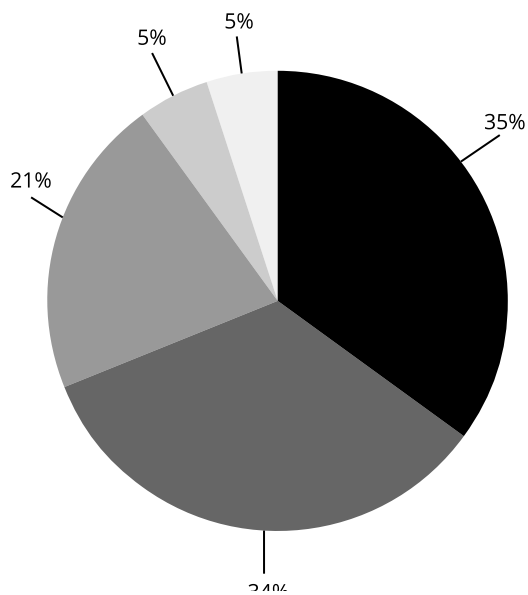

Bio-Manguinhos

Butantan Institute

International laboratories

FAP

Funed

FAP: State Research Foundations; Funed: Ezequiel Dias Foundation.

Source: Bio-Manguinhos, Oswaldo Cruz Foundation, 2019.

Research Council (CNPq), Brazilian Graduate Studies Coordinating Board (CAPES), State Research Foundations (FAPs), Funding Authority for Studies and Projects (FINEP) and the National Bank for Economic and Social Development (BNDES). Most funding initiatives are focused on individual "bydemand" projects with pulverization of efforts. It is necessary thus to induce and rigorously monitor RD\&I performance of public and private laboratories, increasing competitiveness among national companies. The current scenario of low competitiveness is exacerbated by both the accelerated way in which the new vaccines are developed and economic crises, leading to budget cuts that threaten the development and production processes.

Another aspect that deserves reflection and deep change is the excess of bureaucratic formalism and regulation in order to organize scientific and technological activities, which have an inhibiting effect on innovation. It is necessary, therefore, to create and stimulate an institutional and regulatory environment with the necessary flexibility, supported by rigorous methodological procedures and the set of scientific evidence gathered in the whole process, in the flow of discovery to the final product. The future project development may need to have as main investigators professionals from the regulatory authorities associated with the Solicitor-General of Brazil (AGU), to avoid the many steps and delays in each of these official cabinets. They must come together to enable the development of a new vaccine, important for the public health.

As Thomas Kuhn points out in his work The Structure of Scientific Revolutions 35, the authentic evolution of science translates into a revolution, that is, a break with the current paradigm and the adoption of a new paradigm.

The innovation process is not cumulative, as usually believed. In fact, it emerges from a rupture. It is a revolution, from the rupture with the currently established practices that is necessary, so that vaccine innovation can effectively occur in our country. It is important to understand that innovation is the end of all investments in the innovation chain. To register new innovative vaccine products, we need hundreds or thousands of good projects at the beginning of the chain. 


\section{Strategies}

\section{Long-term sustainable financing}

In the current complex transition scenario towards a new configuration of the global vaccine market and Vaccinology 4.0, countries have been conducting a thorough review of their funding mechanisms and incentives for their vaccine R\&DI and production. To that end, they have been reformulating their governance structures and processes, focused on increasingly centralized and strongly inductive and sustainable long-term financing strategies, avoiding dispersion of efforts. Brazil urgently needs to review its financing strategies, currently dispersed in several institutions such as FINEP, FAPs, CNPq, Secretariat of Science, Technology and Strategic Inputs (Ministry of Health), BNDES and others.

Recent data indicate the accelerated growth of the global vaccine market. The growth forecast for this market from 2016 to 2021 is $8.3 \%$ (Compound Annual Growth Rate - CAGR), with an expansion from USD 32.24 billion in 2016 to USD 48.03 billion in 2021 and estimated to USD 50 billion by 202336 .

Pharmaceutical companies have exponentially increased their investments in RD\&I for biological products (vaccines, biopharmaceuticals and diagnostic reagents, which now account for 20 to $27 \%$ of their revenues) 37.

Table 1 shows the five largest companies operating in the vaccine market and their participation in this market; these companies have reached this position, investing in RD\&I, but also by making partnerships in technological development, buying patents, acquiring emerging companies or even doing business mergers, aiming at market consolidation and at mastering the latest technologies.

\section{Technology transfer and PPD}

In the context of the greatest achievement of smallpox eradication in Brazil, in 1973 the country created the NIP, with only six vaccines in the calendar and currently with 19 vaccines.

By 2014, it achieved high vaccination coverage, with high impact results, such as the eradication of smallpox, poliomyelitis, rubella and measles, and significant reduction of reports of all other immunopreventable diseases. Unfortunately, vaccination coverage has not reached desirable levels recently, causing great concern to health authorities 9,12 .

The PASNI was created in 1985 due to the crisis of production and shortage of immune sera against ophidian venoms and vaccines. The Ministry of Health has invested continuously in the production capacity of public laboratories. Such clear priorities by the Brazilian government at the time were very important expanding and strengthening the installed technological capacity, as well as meeting the demand for strategic inputs such as vaccines.

The use of governmental purchasing power in the SUS has been an essential strategy for the internalization of new production technologies, since it implies the obligation of the holder of the production technology to transfer it in a suitable period for the national laboratory 9. Almost all new vaccines on the international market were incorporated into routine NIP, including the rotavirus vaccine, conjugate pneumococci, meningitis meningococcal serogroup C conjugate, influenza, HPV, conjugated Hib, IPV, triple viral, tetraviral, varicella, DTPa (pregnant women) and, recently, hepatitis A.

Table 1

Five largest companies in the vaccine market, 2018.

\begin{tabular}{lc}
\hline Company & Share (\%) \\
\hline GlaxoSmithKline Plc. & 24.0 \\
Merck and Co. & 23.6 \\
Pfizer & 21.7 \\
Sanofi & 20.8 \\
Novavax & 5.9 \\
\hline
\end{tabular}

Source: Statista 41. 
The new vaccines, when introduced to the market, are only produced by the those who hold the monopoly and charge high prices. These products became available only when the market of developed countries is met, which often requires a few years of waiting for their effective incorporation into the healthcare system 9 .

Since the creation of Bio-Manguinhos and the Instituto Butantan, these two national laboratories, have invested in production, technological development and innovation of immunobiological products.

Several innovations have been made, improving the quality of the vaccines produced locally. Some examples are improvements in production yields through the optimization or development of new processes, in vaccine thermostability, in formulations, in vaccine presentations, and in quality control methodologies.

The design of partnerships for vaccine development is a fragile point, an important gap to be overcome in our country, due to several bureaucratic steps in legal requirements and negotiations that must be finalized to develop a process or product. Despite these difficulties, there are some projects in progress in partnership with different institutions developing the vaccine against Zika, chikungunya, a new vaccine against yellow fever, dengue, malaria, leishmaniasis and other new combined vaccines.

\section{Regulatory flexibility for preparedness and competitiveness}

National compliance with the good manufacturing practices (GMP) has received worldwide acceptance by both health regulatory agencies (such as the World Health Organization - WHO, or the Brazilian National Regulatory Agency - Anvisa) and producers of vaccines and other health supplies.

The GMP and regulatory barriers in the vaccine market have been important constraints to vaccine development, with detrimental impacts on Brazilian vaccine RD\&I and competitiveness. The need for compliance with the new regulatory requirements led to the need for high investments by the production laboratories: the modernization of their facilities, new equipment, new technologies and new organizational structures that could strengthen control and quality. In this regulatory scenario, many vaccine-producing laboratories in developing countries, particularly public vaccine manufacturers, were unable to carry out the necessary modernization and investments and had to cease their activities. Figure 3 shows the major regulatory constraints in the country and their impact on vaccine preparedness for neglected and emerging infectious diseases.

\section{Figure 3}

Regulatory constraints in Brazil: impacts on vaccine preparedness.

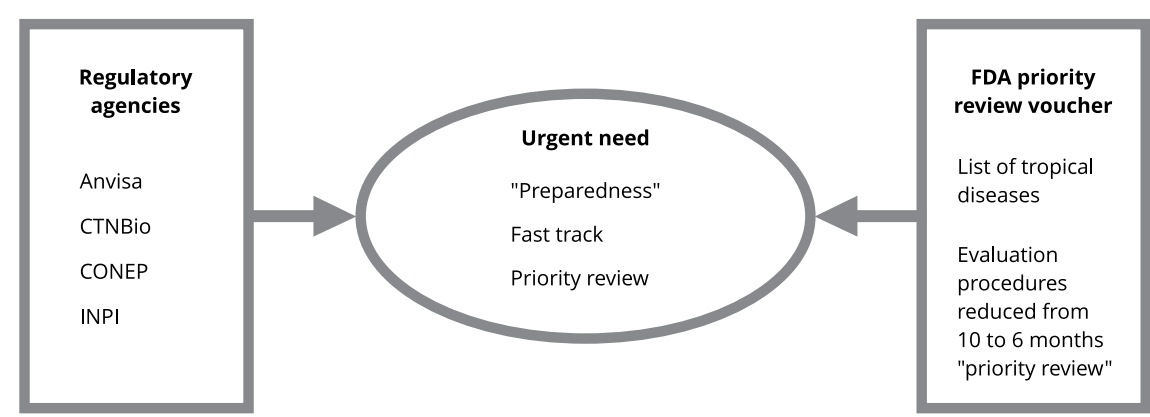

Anvisa: Brazilian National Regulatory Agency; CONEP: National Ethics Research Commission; CTNBio: National Technical Biosafety Commission; FDA: U.S. Food and Drug Administration; INPI: National Institute of Industrial Property.

Source: elaborated by the authors. 
Intellectual property is one of these regulatory barriers constraining the access of the poorest populations worldwide to vaccines. Multinational companies have the intellectual property of new technologies, such as adjuvants for vaccine compositions, but do not have sufficient production capacity to meet the global demand for these products, a gap that must be overcome with the global collaboration extended to vaccine producers in developing countries 15,38 .

Moreover, vaccines are multipatented products 1 with exponentially increasing costs, limiting the access to these products to developing countries. Strategies such as patent pools and incentives to promote collaborative sharing of patents and lower the costs of vaccines are therefore of major importance.

The results of the dynamism provided by these incentives are evidenced in the percentage participation of these countries in patent deposits, with China leading with $36 \%$ of the global deposits, followed by the United States with 33\%. A survey of the Derwent Innovations Index has recovered 6,060 patent filings worldwide between 2008 and 201322.

\section{Epidemic preparedness and vaccine innovation}

RD\&I Institutes and vaccine manufacturers in Brazil and other developing countries need urgently to strengthen their local research conditions in order to be integrated into a global preparedness strategy. The challenge to develop vaccines against emerging neglected diseases that primarily strike the poor and now for COVID-19 pandemic is taken by the Coalition of Epidemic Preparedness Innovations (CEPI), a public-private coalition that aims to derail epidemics by speeding up the development of vaccines up to phase II of clinical trials. CEPI in now playing a major role in COVID-19 vaccine RD\&I.

Conceiving global governance strategies is a major challenge for preparedness in vaccine development. CEPI was created as a global model by the Norwegian government, funding agencies and stakeholders. Conceptually, CEPI supports platform technologies, seeks worldwide expertise, and puts them together, in order to expedite the required vaccine development.

A CEPI study estimated the costs of developing vaccines for diseases that could escalate into global humanitarian crises ${ }^{39}$. This study analyzed 11 diseases, including MERS, Lassa, Nipah, chikungunya, Rift Valley fever and preparedness for disease X. The results indicated that it would cost between USD 2.8 billion and USD 3.7 billion to develop at least one vaccine for each of them. These costs are low if considered the potential costs of outbreaks of these diseases and the dramatic consequent global epidemiological impacts. The 2003 SARS outbreak in East Asia had a cost of USD 54 billion.

CEPI is funded by the Welcome Trust, the Bill and Melinda Gates Foundation, the European Commission and several governments (Norway, Japan, Germany, Canada, Australia, United Kingdom, Belgium and other donors) 37 .

\section{Vaccine governance: urgent need for a new framework}

The institutional, financial, regulatory and bureaucratic constraints to vaccine development in the country described here stress the urgent need for a thorough review of the current Brazilian RD\&I vaccine policy strategy. It will be necessary to conceive and implement new structures and strategies of governance, with permanent monitoring, quality control and evaluation of vaccine projects, as indicated in Box 1. The creation of two new institutional national structures (National Technical Immuno Commission - CTN-Immuno and a "CEPI-like" national funding mechanism - a Brazilian Coallition for Epidemic Preparedness Innovations), operating in a complementary way, will be key components in this new governance framework supported by more flexible regulatory procedures ${ }^{9}$. The transformation of Bio-Manguinhos into a public company (ongoing process in the Brazilian government) will also be crucial to accelerate vaccine RD\&I and production in the country. 
Box 1

Governance strategies to accelerate vaccine research, development and innovation (RD\&l) in Brazil.

\begin{tabular}{|c|c|c|c|c|c|}
\hline TIMELINE & GOVERNANCE & FUNDING & INFRASTRUCTURE & REGULATORY & $\begin{array}{l}\text { CAPACITY } \\
\text { BUILDING }\end{array}$ \\
\hline Short-term & $\begin{array}{l}\text { Create CTN-Immuno } \\
\text { linked to Ministry of } \\
\text { Health/Bio-Manguinhos } \\
\text { and supported by the } \\
\text { Ministry of Science, } \\
\text { Technology and Innovation } \\
\text { for prioritization and } \\
\text { systematic evaluation/ } \\
\text { monitoring of vaccine RD\&l } \\
\text { projects } \\
\text { Bio-Manguinhos } \\
\text { transformed into public } \\
\text { company } \\
\text { Exponentially increase in } \\
\text { institutional and financial } \\
\text { support to public vaccine } \\
\text { manufacturers (Bio- } \\
\text { Manguinhos, Butantan } \\
\text { Institute, Tecpar, and } \\
\text { other) }\end{array}$ & $\begin{array}{c}\text { Create Vaccine } \\
\text { Preparedness } \\
\text { Funding mechanism } \\
\text { for priority } \\
\text { emerging diseases } \\
\text { and disease X: } \\
\text { "Brazilian CEPI" } \\
\text { Vaccine projects } \\
\text { approved and } \\
\text { monitored by CTN- } \\
\text { Immuno }\end{array}$ & $\begin{array}{c}\text { New API facilities } \\
\text { Pilot plant } \\
\text { Support to the } \\
\text { Industrial Complex } \\
\text { of Biotechnology for } \\
\text { Health (Santa Cruz/Rio } \\
\text { de Janeiro State) } \\
\text { Support to the Center } \\
\text { for Plant-derived } \\
\text { vaccines - tobacco } \\
\text { plants (Eusebio/Ceará } \\
\text { State) }\end{array}$ & $\begin{array}{l}\text { Incentives to } \\
\text { exponentially } \\
\text { increase number } \\
\text { of vaccine patents } \\
\text { in Brazil } \\
\text { Incentives: } \\
\text { awards, prizes, } \\
\text { "patent-pools", } \\
\text { new funding } \\
\text { mechanisms, } \\
\text { credit. } \\
\text { NRA compliance }\end{array}$ & $\begin{array}{l}\text { Capacity building of } \\
\text { vaccine technicians: } \\
\text { Specialization and } \\
\text { Graduate Courses } \\
\text { (Master/Doctoral) } \\
\text { Create incentive } \\
\text { mechanisms for } \\
\text { reversal of "brain } \\
\text { drain," attracting to } \\
\text { Brazilian institutes } \\
\text { and universities } \\
\text { researchers who are } \\
\text { abroad }\end{array}$ \\
\hline Medium-term & $\begin{array}{c}\text { Elaborate/implement } \\
\text { National Vaccine RD\&l/ } \\
\text { Production Strategic Plan } \\
\text { for next } 20 \text { years } \\
\text { Evaluate and promote } \\
\text { public-private partnerships } \\
\text { for vaccine RD\&l } \\
\text { Drastically reduce } \\
\text { bureaucratic and legal } \\
\text { barriers to governance/ } \\
\text { management }\end{array}$ & $\begin{array}{l}\text { Multi-institutional } \\
\text { vaccine funding } \\
\text { mechanism } \\
\text { Overcome pre- } \\
\text { clinical gap } \\
\text { increasing Brazilian } \\
\text { competitive } \\
\text { participation } \\
\text { in multicentric, } \\
\text { multinational } \\
\text { studies }\end{array}$ & $\begin{array}{c}\text { Vaccine RD\&l } \\
\text { infra-structure } \\
\text { implemented } \\
\text { supported and } \\
\text { monitored by CTN- } \\
\text { Immuno, Federal } \\
\text { and State Funding } \\
\text { Agencies and partner } \\
\text { private companies }\end{array}$ & $\begin{array}{l}\text { Expedited "fast- } \\
\text { track" procedures } \\
\text { in evaluations } \\
\text { (Anvisa, CONEP, } \\
\text { CTNBio) } \\
\text { Increase } \\
\text { regulatory } \\
\text { flexibility to } \\
\text { respond to } \\
\text { new emerging } \\
\text { infectious } \\
\text { diseases }\end{array}$ & $\begin{array}{c}\text { Graduate programs } \\
\text { in vaccine RD\&l } \\
\text { and production } \\
\text { (institutional and } \\
\text { multi-institutional) } \\
\text { Graduate Programs } \\
\text { in Vaccine Policy/ } \\
\text { Management }\end{array}$ \\
\hline Long-term & $\begin{array}{l}\text { Achieve goals of National } \\
\text { Vaccine PD\&l and } \\
\text { Production Strategic Plan } \\
\text { by } 2040\end{array}$ & $\begin{array}{l}\text { Evaluate Strategic } \\
\text { Plan from Global } \\
\text { Sustainability } \\
\text { perspective and } \\
\text { redefine goals } \\
\text { and funding } \\
\text { mechanisms }\end{array}$ & $\begin{array}{l}\text { Evaluate results/goal } \\
\text { achievement } \\
\text { Vaccine infrastructure } \\
\text { in Brazil in full } \\
\text { operation by } 2030 \\
\text { and recognized } \\
\text { internationally }\end{array}$ & $\begin{array}{c}\text { Evaluate the } \\
\text { impacts of } \\
\text { incentives and } \\
\text { flexible regulation } \\
\text { on vaccine RD\&l } \\
\text { and production } \\
\text { WHO } \\
\text { prequalification }\end{array}$ & $\begin{array}{l}\text { Evaluate the } \\
\text { outcome and impact } \\
\text { of capacity building } \\
\text { programs }\end{array}$ \\
\hline
\end{tabular}

Anvisa: Brazilian National Regulatory Agency; API: active pharmaceutical ingredients; CEPI: Coalition for Epidemic Preparedness Innovations; CONEP: National Ethics Research Commission; CTNBio: National Technical Biosafety Commission; CTN-Immuno: National Technical Immuno Commission; NRA: national regulatoy agencies; WHO: World Health Organization. Source: elaborated by the authors. 


\section{Final considerations}

Brazilian public producers have been active in the development and production of vaccines for human use for over 100 years, creating tradition, reliability, competence as well as demonstrating their strategic importance for the country. In several occasions, public health needs were prioritized; such as in Oswaldo Cruz work to eradicate the Aedes aegypti and yellow fever from Rio de Janeiro, Alcides Godoy's cattle vaccination, which made possible the survival of cattle breeding in the country, the discovery of the Chagas disease etiologic agent by Carlos Chagas, the crucial role of Henrique Penna in developing the yellow fever vaccine, and many other examples. Besides avoiding shortages, public laboratories have contributed to the regulation of prices of vaccines, saving vast amounts of money.

However, with an average of 10 to 15 years and an estimated cost of USD 2.6 billion to develop a new vaccine, the instruments used in vaccine development need to start adding value from the moment they are installed 21,40. Emerging technologies, particularly disruptive ones, which bring the prospect of high-throughput technologies able to deliver huge volumes of vaccine using simpler upstream and downstream equipment and procedures, are incorporated by leading multinational companies in their search for new manufacturing strategies and scales.

In this scenario of COVID-19 pandemic and rapid changes, the main challenges for the public laboratory producers are the search and incorporation of new technologies of production and new vaccines, the improvement of technological competitiveness, self-sustainability and professional management. In addition, it will be a great challenge to meet the requirements of regulatory agencies for high quality immunobiological products, which should put more pressure on the industry to incorporate new analytical technology to ensure better confidence in results and lower manufacturing cost 21 .

The new "mission-oriented" governance framework proposed here is an important window of opportunity for Brazil to develop innovative vaccine projects against major emerging and neglected diseases, which mainly affect poor countries. Many of these projects are already in proof-of-concept, but, due to lack of commercial interest, they end up falling into the so-called "valley of death". Brazil could seek partnerships with the laboratories that hold these technologies and lead with other emerging countries such as China, South Korea and India, an international mobilization to conceive and implement a Global Fund and a Collaborative Governance Plan focused on RD\&I and production of vaccines for these diseases.

\section{Contributors}

All the authors have contributed equally to the article.

\section{Additional informations}

ORCID: Akira Homma (0000-0002-4641-8491); Marcos da Silva Freire (0000-0002-4723-8994); Cristina Possas (0000-0002-2886-2812).

\section{References}

1. Bragazzi NL, Gianfredi V, Villarini M, Rosselli R, Nasr A, Hussein A, et al. Vaccines meet big data: state-of-the-art and future prospects. From the classical 3Is ("isolate-inactivate-inject") Vaccinology 1.0 to Vaccinology 3.0, Vaccinomics, and beyond: a historical overview. Front Public Health 2018; 6:62.

2. Poland GA, Kennedy RB, Ovsyannikova IG. Vaccinomics and personalized vaccinology: is science leading us toward a new path of directed vaccine development and discovery? PLoS Pathog 2011; 7:e1002344.

3. Sette A, Rappuoli R. Reverse vaccinology: developing vaccines in the era of genomics. Immunity 2010; 33:530-41.

4. Possas C, Antunes AMS, Mendes FML, Schumacher SOR, Martins RM, Homma A. Access to new technologies in multipatented vaccines: challenges for Brazil. Nature Biotech $2015 ; 33: 599-603$. 
5. Rappuoli R, Black S, Lambert PH. Vaccine discovery and translation of new vaccine technology. Lancet 2011; 378:360-8.

6. Telarolli JR. Histórico da vacinação antivariólica no Brasil. Rev Ciênc Farm 1999; 20:461-70.

7. Hochman G. Vacinação, varíola e uma cultura da imunização no Brasil. Ciênc Saúde Colet 2011; 16:375-86.

8. Possas C, Lourenço-de-Oliveira R, Tauil PL, Pinheiro FP, Pissinatti A, Cunha RV, et al. Yellow fever outbreak in Brazil: the puzzle of rapid viral spread and challenges for immunisation. Mem Inst Oswaldo Cruz 2018; 113:e180278.

9. Possas C, Homma A, Risi Jr. JB, Ho PL, Camacho LAB, Freire MS, et al. Vacinas e vacinações no Brasil: Agenda 2030 na perspectiva do desenvolvimento sustentável. Relatório Saúde Amanhã. Rio de Janeiro: Fundação Oswaldo Cruz; 2019.

10. Wilder-Smith A, Gubler DJ, Weaver SC, Monath TP, Heymann DL, Scott TW. Epidemic arboviral diseases: priorities for research and public health. Lancet Infect Dis 2017; 17: e101-6.

11. Belluck P, Abelson K. Vaccine injury claims are few and far between data from a federal program designed to compensate people harmed by vaccines shows how rare it is for someone to claim they were hurt after getting vaccinated. The New York Times 2019; 18 jun. https:// www.nytimes.com/2019/06/18/health/vac cine-injury-claims.html.

12. Ministério da Saúde. 100 dias de governo: ações buscam reverter queda na taxa de vacinação no país. http://www.brasil.gov.br/ 100dias/noticias/acoes-buscam-reverter-que da-na-taxa- de-vacinacao-no-pais/\#conteudo (accessed on 12/apr/2019).

13. Bloom DE, Cadarette D. Infectious disease threats in the twenty-first century: strengthening the global response. Front Immunol 2019; 10:549.

14. World Health Organization. Epidemiological report. Geneva: World Health Organization; 2018.

15. Kaslow DC, Black S, Bloom DE, Datla M, Salisbury D, Rappuoli R. Vaccine candidates for poor nations are going to waste. Nature 2018; 564:337-9.

16. Mesquita EC, Conceição DA, Oliveira PMN, Barros TAC, Zhang Q, Hernandez N, et al. Genetic basis for yellow fever vaccine-associated viscero-tropic disease (YEL-AVD): a preliminary report. In: Annals of the IV International Symposium on Immunobiologicals/VII Seminário Anual Científico e Tecnológico. Rio de Janeiro: Instituto de Tecnologia em Imunobiológicos, Fundação Oswaldo Cruz; 2019. p. 59.

17. Jouanguy E. Human genetics and susceptibility to infectious diseases and challenges for vaccine design. In: Annals of the IV International Symposium on Immunobiologicals/VII Seminário Anual Científico e Tecnológico. Rio de Janeiro: Instituto de Tecnologia em Imunobiológicos, Fundação Oswaldo Cruz; 2019.
18. Soto C, Bombardi RG, Branchizio A, Kose N, Matta P, Sevy AM, et al. High frequency of shared clonotypes in human B cell receptor repertoires. Nature 2019; 566:398-402.

19. Briney B, Inderbitzin A, Joyce C, Burton DR. Commonality despite exceptional diversity in the baseline human antibody repertoire. $\mathrm{Na}$ ture 2019; 566:393-7.

20. Possas C, Antunes AMS, Mendes FML, Martins RM, Homma A. Emerging and resurgent arboviral diseases: global vaccine patent landscape and the case for immunome. In: Singh H, Keswani C, Singh S, editors. Intellectual property issues in microbiology. Singapore: Springer; 2019. p. 337-52.

21. Barbano D. Innovation, network and biotechnological partnerships. New challenges for biopharmaceutical process development transforming the way WHO-regulated products are developed, evaluated and manufactured. In: Annals of the IV International Symposium on Immunobiologicals/VII Seminário Anual Científico e Tecnológico. Rio de Janeiro: Instituto de Tecnologia em Imunobiológicos, Fundação Oswaldo Cruz; 2019.

22. Possas C, Antunes A, Mendes FML, Martins RM, Homma A. Innovation and intellectual property issues in the "decade of vaccines": a Brazilian perspective. In: Singh HB, Jha A, Keswani $\mathrm{C}$, editors. Intellectual property issues in biotechnology. Wallingford: CABI; 2016. p. 181-92.

23. Mazzucato M. The people's prescription: reimagining health innovation to deliver public value. London: UCL Institute for Innovation and Public Purpose; 2018.

24. Mazzucato M, Penna C. Mission-oriented finance for innovation: new ideas for investment-led growth. London: Rowman \& Littlefield International; 2015.

25. Homma A, Martins RM, Jessouroum E, Oliva $\mathrm{O}$. Desenvolvimento tecnológico: elo deficiente na inovação tecnológica de vacinas no Brasil. Hist Ciênc Saúde-Manguinhos 2003; 10 Suppl 2:671-96.

26. Martins RM, Maia MLS, Homma A, Mingowski E. Autossuficiência no Brasil para a produção de imunobiológicos. In: Amato Neto $\mathrm{V}$, editor. Atualizações, orientações e sugestões sobre imunizações. São Paulo: Segmento Farma; 2011. p. 113-6.

27. Ponte CF. Vacinação, controle de qualidade e produção de vacinas no Brasil a partir de 1960. Hist Ciênc Saúde-Manguinhos 2003; 10 Suppl 2:619-54.

28. Homma A, Tanuri A, Duarte AJS, Marques E, Almeida A, Martins, RM, et al. Vaccine research, development, and innovation in Brazil: a translational science perspective. Vaccine 2013; 315:854-60.

29. Jodar L, La Force M, Ceccarini C, Aguado T, Granoff DM. Menigococcal conjugate vaccine for Africa: a model for development of new vacines for the poorest countries. Lancet 2003; 361:1902-4. 
30. La Force M, Konde K, Viviani S, Préziosi MR. The Meningitis Vaccine Project. Vaccine 2007; 25:A97-100.

31. Plotkin AS. History of vaccine development. New York: Springer: 2011.

32. Stamm B, Trifilova A. The future of innovation. Farnham: Gower Publishing Co.; 2009.

33. Possas C, Martins RM, Homma A. Vaccine innovation and global sustainability: governance challenges for Sustainable Development Goals. In: Adenle AA, Chertow MR, Moors EHM, Pannell DJ, editors. Science, technology and innovation for Sustainable Development Goals: insights from agriculture, health, enviroment, and energy. New York: Oxford University Press; 2020. p. 219-42.

34. Stokes DE. O quadrante de Pasteur. A ciência básica e a inovação tecnológica. Campinas: Editora Unicamp; 2009.

35. Kuhn TS. The structure of scientific revolutions. Chicago: University of Chicago Press; 1962.

36. MarketsandMarkets. Vaccine markets by diseases and technologies, report 2019. https:// www.marketsandmarkets.com/Market-Re ports/vaccine-technologies-market-1155.html (accessed on 22/Mar/2019).
37. Clemens R. Biopharmaceutical innovation and global health: how to be ready for the unknown? In: Annals of the IV International Symposium on Immunobiologicals/VII Seminário Anual Científico e Tecnológico. Rio de Janeiro: Instituto de Tecnologia em Imunobiológicos, Fundação Oswaldo Cruz; 2019.

38. Netscribes. Top 10 - top players in the biological market, 2019. https://www.netscribes. com/about-us/media/press-releases/page/3/ (accessed on 15/Apr/2019).

39. Brende B, Farrar J, Gashumba D, Moedas C, Mundel T. Shiozaki Y, et al. CEPI - a new global R\&D organisation for epidemic preparedness and response. Lancet 2017; 389:233-5.

40. Hong MS, Severson KA, Jiang M, Lu AE, Love JC, Braatz RD. Challenges and opportunities in biopharmaceutical monitoring control. Comput Chem Eng 2018; 110:106-14.

41. Statista. Global pharmaceutical industry - statistics and facts. https://www.statista.com/ topics/1764/global-pharmaceutical-industry/ (accessed on 22/Apr/2019). 


\section{Resumo}

Examinamos as implicações da competitividade tão baixa do sistema brasileiro de pesquisa, desenvolvimento e inovação (PDerI) de vacinas, que impede o desenvolvimento de todas as vacinas importantes requeridas pelo Programa Nacional de Imunizações (PNI), prejudicando gravemente a saúde da população. Em um país seriamente afetado pela pandemia de COVID-19 e por um aumento exponencial de doenças emergentes e negligenciadas, principalmente entre os brasileiros pobres, essas restrições de PDerI quanto às vacinas tornam-se questões cruciais de governança. Essas restrições são agravadas por um cenário global de interesse comercial limitado por parte das empresas multinacionais de vacinas para doenças negligenciadas e emergentes, que estão caindo em um "vale da morte", com apenas duas vacinas produzidas em um pipeline de 240 vacinas. Ressaltamos que essas restrições na produção global constituem uma janela de oportunidade para os fabricantes de vacinas no Brasil e em outros países em desenvolvimento na atual transição de paradigma para a Vacinologia 4.0. Concluímos com recomendações para uma nova estratégia de governança em suporte aos fabricantes públicos de vacinas no Brasil em colaborações internacionais para um plano nacional de desenvolvimento e produção de vacinas que seja sustentável até 2030.

Vacinas; Pesquisa Científica e Desenvolvimento Tecnológico; Governança

\section{Resumen}

Examinamos las implicaciones de la muy baja competitividad del sistema brasileño de IDerI de vacunas, que imposibilita el desarrollo de todas las vacunas importantes, requeridas por el Progrma Nacional de Inmunización (PNI), con impactos muy graves en la salud de la población de un país con 200 millones de habitantes. En un país gravemente afectado por la pandemia de COVID-19 $y$ por enfermedades emergentes $y$ olvidadas que afectan particularmente a los pobres, estas restricciones del IDerI para vacunas es, de hecho, un asunto crucial de gobierno. Estas limitaciones locales se han visto agravadas por un escenario global de interés comercial limitado, por parte de las compañias multinacionales, en vacunas para enfermedades emergentes y olvidadas, que están cayendo en un "valle de la muerte", con solamente dos vacunas producidas a nivel global frente a 240 vacunas. Identificamos en estas limitaciones globales una ventana de oportunidad para los fabricantes de vacunas en Brasil y otros países en desarrollo dentro del paradigma actual de transición hacia la Vacunología 4.0. Concluimos con recomendaciones de una nueva estrategia de gobierno que apoye a los fabricantes brasileños de vacunas públicas en colaboraciones internacionales para el plan nacional de desarrollo y producción sostenible de vacunas en 2030.

Vacunas; Investigación Científica y Desarrollo Tecnológico; Gobernanza
Submitted on $22 / \mathrm{Jul} / 2019$

Final version resubmitted on 23/Nov/2019

Approved on 06/Dec/2019 